\title{
Figures from the Past: Sargeson's Wandering Men and the Limits of Nationalism ${ }^{1}$
}

\section{PHILIP STEER}

It is time to forget about his being a 'national' writer, certainly time to cease thinking of him as a 'realist'. Think instead of affinities with another 'colonial' writer[.] Frank Sargeson, 'Henry Lawson: Some Notes after Re-Reading'

Frank Sargeson's repositioning of Henry Lawson as a 'colonial' writer, away from the more familiar categories of nationalism and realism, offers a provocation for re-considering his own short fiction. In taking up that challenge, this essay diverges from recent attempts to trouble the periodization of writing from the 1930s and 40s: rather than arguing that the concerns of cultural nationalism were anticipated in the nineteenth-century, it will make the case that colonial literary forms and cultural formations persist in some of the most familiar works of that later period. Focusing on Sargeson's frequent recourse to solitary male characters in his short stories, I will begin by suggesting that their geographic mobility and nostalgic tendencies mark them as anachronistic 'figures from the past', lacking any social or economic place within contemporary society. The formal contours of the short story are silently troubled by such figures, for as the story 'Last Adventure' makes especially clear, their realist aesthetic is underpinned by an episodic and anecdotal structure that refract the nineteenth-century adventure romance. Sargeson's critical writings on Australian subjects help bring these vestigial traces of the romance productively into focus as formal reflections of broader trans-Tasman linkages of labour, politics and culture that were by the 1930s beginning to seem untenable and unimaginable. The short stories, in other words, can be reconsidered as laments for a colonial era that seemingly offered greater political and cultural possibilities than an increasingly bounded national present.

I wish to begin with what may seem a fairly commonplace observation, namely, that the solitary male figures at the centre of so many of Sargeson's short stories tend not to stand still for very long. Their intrinsic mobility is exemplified by the framing of one of his most famous stories, 'The Making of a New Zealander' (1939), which begins:

When I called at that farm they promised me a job for two months so I took it on, but it turned out to be tough going. The boss was all right, I didn't mind him at all, and most days he'd just settle down by the fire and get busy with his crochet. [...] But this story is not about a cocky who used to sit in front of the fire and do crochet. I'm not saying I haven't got a story about him, but I'll have to be getting round to it another time. ${ }^{2}$

From the outset, the story signals that the narrator's stay at the farm will only be temporary, because of the nature of the work and because of his temperament. The short story form suits to such a figure, for its brief and fragmentary nature matches the discontinuous anecdotal reflections that he wants to get off his chest. 'Now I'm running on ahead so I'd better break off again', he announces, 'What I want to tell is about how I sat on a hillside one evening and talked with a man. That's all, just a summer evening and a talk with a man on a hillside'. ${ }^{3}$ That conversation with Nick, an immigrant from Dalmatia working on the neighbouring property, circles around the paradox of inhabiting a national space but not conforming to its dominant values: 'Nick was saying he was a New Zealander, but he knew he wasn't a New Zealander'. ${ }^{4}$ In keeping with the fragmentary nature of their encounter, the story concludes abruptly with the narrator being fired the next morning and resuming his migratory ways: 'I stood on the road and wondered if I'd go up to Nick's place, but instead I

Journal of New Zealand Studies NS13 (2012), 34-45. 
walked into town, and for a good few days I never left off drinking'. ${ }^{5}$ The narrator's geographic unsettlement is thus closely related to, and is symbolic of, the formal and thematic dislocations staged in the story in opposition to a bounded sense of New Zealand identity.

Inseparable from their mobility, Sargeson's solitary male figures are also characterized by intense emotional investments in the past. The complex intersection of wandering and nostalgia is particularly evident in the disenchantment of the narrator of 'An Affair of the Heart' (1936). He too has 'never been able to settle down': unlike his brother, a 'successful business man, with a wife and a car and a few other ties that successful men have', he has lived an itinerant lifestyle, 'meeting different people and tackling all sorts of jobs, and if I've saved up a few pounds it's always come natural to me to throw up my job and travel about a bit' ${ }^{6}$ While 'walking northwards to a job on a fruit-farm', this rolling stone returns after a twenty-year hiatus to the Auckland beach where he spent his summer holidays:

Well, it's all a long time ago. It's hard now to understand why the things that we occupied our time over should have given us so much happiness. But they did. As I'll tell you, I was back in that bay not long ago, and for all I'm well on in years I was innocent enough to think that to be there again would be to experience something of that same happiness. Of course I didn't experience anything of the kind. ${ }^{7}$

In addition to being the scene of happy experiences, however, it was at the beach where their encounters with Mrs Crawley and her children first confronted the narrator and his brother with the reality of poverty, something 'that made us feel a little frightened'. ${ }^{8}$ More disconcerting to them, apparently, is the strength of Mrs Crawley's feelings for her son, Joe, which contrast with the reserve of their own family and the 'petty and mean' values of contemporary society. ${ }^{9}$ The narrator's inability to 'settle down' has a double valence, simultaneously resisting the bourgeois trappings of modern success and reacting to the emotional intensity of the past, so that whether or not the past was better for him his alienation from the present is linked psychologically and thematically to those nomadic propensities.

The relation of settler writers to the past, and in particular the stance adopted by them in the 1930s and 40s, has attracted some incisive commentary in recent years. Stephen Turner has argued that settler identity is fundamentally melancholic due to the wide-ranging repression of the past, and is reflected in a 'settler realism' characterized by '[t]he habit of laconic understatement, the acknowledgement of common experience in shared silence and the ready tendency to agree'. ${ }^{10}$ More recently, John Newton has also employed the notion of melancholia to assert Denis Glover's central role in the 'naturalization' of settlement. The Sings Harry sequence, Newton argues, seeks 'an imaginative occupation and imaginative possession [of the land] — achieved, paradoxically enough, through nostalgia and dispossession', that is, through the wandering figure of Harry. ${ }^{11}$ The 'melancholy affect' embodied by Harry is, crucially, driven 'not [by] the anxiety of alienation but [by] the sorrow of dispossession':

Glover's persona sings in the present in order to articulate the achievement of a past. Settlement now has a history: it remembers. And the function of a dispossession in that memory is to attest to a depth of occupancy. [...] [I]f the settler's claim to occupancy is voiced as dispossession, the 'proof' of that dispossession is exhibited in the voice's prevailing melancholy. ${ }^{12}$

Patrick Evans draws heavily on Newton's argument in The Long Forgetting (2007), but whereas Newton carefully distinguishes Glover from Sargeson, Evans argues that they are

Journal of New Zealand Studies NS13 (2012), 34-45. 
employed upon a shared project of Pakeha indigenization: 'Like Glover's Harry, the "Sargeson" of Sargeson has become a victim, has been dispossessed-has "become Māori", offering a "final dematerialisation that represents the "settlement of settlement". ${ }^{13}$ Here I wish to reassert the usefulness of Newton's claim that naturalization is a 'multivalent settler trope' that writers approached and adopted in a variety of ways. Unlike Glover's dispossessed Harry, Sargeson's narrators are often alienated - 'lonely men: not men without emotions but men who suffer from a sort of impediment of feeling or who cannot establish a relation where their emotions can be adequately expressed ${ }^{14}$ — and this illuminates a different relationship between the national present and its colonial origins. Rather than attesting to a 'depth of occupancy' that legitimates the present, their mobility is framed as once having had a place within settler culture but now making less and less sense in an urbanizing society.

Therefore, while many of Sargeson's stories are set during the Great Depression, it is important to recognize that the itinerancy of their solitary male protagonists often predates that time. In a similar fashion, many of their most resonant settings are also often associated with a prior era. The most significant and complex of these sites is the farm, which signifies the antithesis to contemporary urbanization at the same time as invoking settlement's thorough transformation of the landscape. ${ }^{15}$ In the late story 'Just Trespassing, Thanks' (1964), the retired narrator Edward Corrie is not a rolling stone but a 'suburban recluse', and his house constitutes the last vestige of the farmland that preceded the suburb:

The large area enclosed by an untidy hedge was known to the inhabitants of the suburb as Corrie's corner; but to Edward it was all that remained of his grandfather's farm, the scene of summertime explorations during school holidays more than sixty years ago and more. He remembered paddocks with creeks and creekbanks; trees, some of them native; scrub on the hillsides; besides his grandfather's cows there had been an orchard, and one season a crop of wheat. Many abstract forces had been at work since those days, and bulldozers and builders had done all the rest: in every direction variety had been replaced by rolling hillsides covered with tile roofs. ${ }^{16}$

Corrie inhabits and remembers a fragment of settler history that has otherwise been erased from the landscape by the homogenizing 'abstract forces' of capitalist modernity, which are producing new social relations out of the land's spatial reconfiguration. The farm is more explicitly associated with the early history of settlement in 'Old Man's Story' (1940), a title that typifies the retrospective bent of so much of the short fiction and that accordingly presents a district on the cusp of modernity:

It was a nice place, he said, an old place in a part of the country that had been settled very early. The farms round about were all old places, most of them were run by the families that had been the first to settle there. There were old orchards everywhere, and plenty of trees, English trees that had been planted right at the beginning. ${ }^{17}$

Despite being connected to urban centres by a branch line, 'there weren't many trains and they'd run at any old times', signifying the disconnection of the 'old fashioned' farm and the district from the homogeneous empty time of the nation. ${ }^{18}$ The tale that the old man recounts, from time spent in his youth on his uncle's farm, concerns a paedophilic relationship between Bandy, a compulsive yarn-spinner who 'turned up one day with a swag on his back', and Myrtle, 'thirteen or fourteen years old, perhaps, and small for her age'. ${ }^{19}$ What he recalls as a seemingly innocent mutual attraction is juxtaposed with his uncle's demands for propriety and legality, so that Bandy's suicide at the story's conclusion comes to symbolize the district's incorporation within a more bounded, regulated, and modern society. 
As is made clear in his memoirs and Michael King's biography, Sargeson's portrayal of these pastoral settings was shaped by his experiences on his uncle's farm near Okahukura in the King Country. In Sargeson's account, the farm offered a recapitulation of the history of settlement:

It had been as though when he took up his land in the year 1913 he returned to European beginnings in New Zealand a hundred years previously, cramming into seven years a sort of small-scale repetition of his country's history - repeating in his ignorance, as he would later on admit, some of the worst mistakes the pioneers had made. ${ }^{20}$

Despite its King Country location, the Okahukura version of settlement avoids any explicit engagement with the causes and consequences of Maori dispossession - as do most of the short stories, with the notable exception of 'White Man's Burden' (1936) — focusing instead on the physical transformation of the landscape and its environmental cost. Despite this, Sargeson's idealized pastoral landscape is never emptied of human presence. King recounts that Sargeson also saw Okahukura as a nexus of pioneer masculine sociality that was deeply interesting and attractive:

Norris [i.e. Sargeson] was also making notes for stories based on some of his uncle's yarns about his boyhood and his life on the farm [...] Norris found these tales 'all so extremely interesting. And of course I also became interested in the characters of the people who had to engage in this sort of work and the way they behaved, the way they talked .... all this feeling for the heartier kind of male friendship, comradeship and so forth'[.] ${ }^{21}$

The anecdotal 'tale' and 'yarn' appear as the natural narrative forms of a labouring community that is also fundamentally rootless. At Okahukura, Sargeson encountered a 'wider male culture of men who are loners, without family ties, very often itinerant workers who strike up friendships with other men in similar circumstances'. ${ }^{22}$ Such biographical insights do not completely account for the stories but they help bring into focus the positive, though often only implicit, valence they attribute to a quasi-nomadic form of masculine labour that is distinctly pre-national in origin.

Sargeson's representations of wandering individuals and colonial-era spaces were also shaped by broader cultural and historical contexts. Miles Fairburn, in The Ideal Society and its Enemies (1989), advanced the influential thesis that colonial Pakeha society was largely characterized by social atomisation. ${ }^{23} \mathrm{He}$ attributed this to the social dislocations of migration itself, the colony's low population density, and the high degree of mobility enabled by the demand for labour:

The lightning expansion of the frontier up to the 1880s pushed most colonists into new areas where they were strangers to one another, and where for an initial period no institutions existed to facilitate mixing and meeting. [...] Foot-loose colonists formed only fleeting relationships. The brief engagement of itinerant workers and their solitary travelling habits prevented them from developing 'mateship' ties. [...] The generally strong labour market, the remarkable resourcefulness of manual workers, and the multitudinous opportunities for petty enterprise converted practically every male and female breadwinner into a masterless man or woman. ${ }^{24}$

According to Fairburn, this atomised society was much closer to the Phoenix generation of writers than might first seem apparent. 'As a living entity', he notes, 'it vanished by the

Journal of New Zealand Studies NS13 (2012), 34-45. 
1920 s after starting to decay from the 1880 s'. ${ }^{25}$ Summarizing and also questioning this analysis, James Belich also identifies a strongly atomised section of male colonial society whose migratory habits sound like a template for Sargeson's short stories:

Drifters were the classic atoms, men alone, drifting from place to place, job to job, without much pattern, by themselves or accompanied by the most casual and temporary acquaintances. [...] [L]one atoms were key producers of the symptoms of atomism; bondless, masterless, extreme individualists who did a lot of bingeing, hitting and being sued, if not suing. ${ }^{26}$

Rather than taking a particular stance on this historiographical debate, at this point I simply wish to note the existence of a popular notion of the atomised colonial male, 'drifting from place to place, job to job, without much pattern', as well as the actual labouring tradition that gave rise to such figures. Both were available to Sargeson and were integrated into the core of his fictional project.

Whether or not the 1920s marked the extinction of the historical figure of man alone, Lawrence Jones has pointed out that the same period saw a profound shift in his literary portrayal. Whereas in colonial writing 'the figure of Man Alone was usually heroic, affirming his society's values', such representations disappear with the advent of cultural nationalism:

If Man Alone as a means of criticizing New Zealand society was relatively rare in the colonial and late colonial fiction before 1930, he became a central figure of the provincial fiction of the 1930s and 1940s, not a hero affirming society's values and dreams but rather a victim of the puritanical and narrowly materialistic society that has subverted those dreams, a society whose flaws were made manifest by the Depression. ${ }^{27}$

While Jones provides ample evidence for this shift from the exemplary to the critical, he has little to say about why this might be the case. A clue can perhaps be found in some of the earliest critical commentary on Sargeson. Writing in 1955, Erik Schwimmer identifies Sargeson's interest in the figure of the 'waif', or modern 'adventurer', who has rejected the trappings of bourgeois life: 'it describes the state of the pioneer and colonist and it describes the state of man after the hope and pride of humanism have broken down'. ${ }^{28}$ Schwimmer's equation of the picaresque 'state of the pioneer and colonist' with a more contemporary form of alienation is a recognition that the critical role of the man alone figure hinges on its origin in the social patterns of a colonial past that have been displaced by a national present.

One way to begin unpacking the cultural logic linking 'the state of the pioneer and colonist' with Sargeson's solitary figures is to differentiate two terms - cultural nationalism and critical realism - that are often used interchangeably in discussions of 1930s writing. The ethos of cultural nationalism is perhaps best captured by Monte Holcroft's essays on literature and culture, and particularly his initial work The Deepening Stream (1940), which sought to discover a New Zealand soul, 'that indestructible work of the collective spirit which can knit a people into a unified group and strengthen it against the struggles and calamities from which no age can hope to escape'. ${ }^{29}$ The task of the writer, according to Holcroft, is to recognize the distinctiveness of that soul in the landscape in particular and to delineate it for their fellow citizens: 'The truth is, I think, that the spirit of a country, recognizable in history and literature, is a kind of collective definition undertaken by a line of creative writers. Only in a receptive and sensitive mind can the undertones and secret values of a countryside be given concrete forms'. ${ }^{30}$ The canonization of Sargeson's short fiction during the 1940s and 50 s as exemplary of an emergent national literature is well known - "none is held to be more 
national than Sargeson', Stuart Murray notes — but it is also important to recognize how widely it diverges from Holcroft's organicist vision of national 'collective definition'. ${ }^{31}$ These short stories seem better described in terms of critical realism, for their representation of a New Zealand vernacular is typically employed as part of a critique of the status quo, and what Murray describes as their 'collapsing [of] author, characters and audience into the same paradigm of cultural egalitarianism' likewise seems unable to imagine a more unified society. ${ }^{32}$ The recent destabilization of nationalist readings of Sargeson includes Murray's highlighting of affinities between his stories and contemporary English writing, and Newton's claim that the 'naturalized closet prose' demanded by his commitment to the local results in the "high-wire duplicity of his own "naturalism". ${ }^{33}$ In contrast to these approaches, however, I wish to explore the possibilities that arise from viewing Sargeson's critical realism as animated by a distinction between the past and the present.

The mobile and nostalgic characters that populate Sargeson's fiction are fundamentally anachronistic, vestiges of a colonial frontier, that he places into uncomfortable juxtaposition with an urbanizing nation. This narrative dynamic is made most explicit in 'Last Adventure' (1937), a story set in another 'very old settled place' by the seaside that has not received any serious critical attention to date. It concerns another 'old man', Fred Holmes, who the narrator encounters while on holiday prior to taking up a job in his father's office. Holmes lives in a 'shack among the sandhills', spatially and developmentally separated from the town, and he first strikes up an acquaintance with the passing schoolboy by offering him a drink of homebrew. ${ }^{34}$ As their relationship develops, the older man begins to recount stories of his 'adventures' in Australasia and the wider Pacific:

His tales were of pearling and wild life in Broome, of life in the mounted police and on the goldfields. Later on he'd come further east and worked on boats running about the islands, for a time he'd run a banana farm in Queensland, and he'd first come to New Zealand in the hope of making a fortune out of picking up ambergris. ${ }^{35}$

Holmes' experiences, in other words, are an almost stereotypical account of life on a colonial frontier that spans multiple countries. His itinerant life has followed, as Belich puts it in another context, the empire's 'spasms of war, gold and progress' around the Pacific rim. ${ }^{36}$ 'He looked very old to me', the narrator recalls, underscoring the sense that Holmes is akin to an anthropological 'survival', a kind of missing link between New Zealand's colonial past and its urbanized present. ${ }^{37}$

The significance of 'Last Adventure' lies in the first instance in the fact that its disenchanted view of contemporary New Zealand society, so clearly of a piece with much of Sargeson's short fiction, is uniquely framed here in historical terms. The narrator and Holmes come from similarly middle-class backgrounds - their fathers are, respectively, an accountant and a solicitor - and the younger man is struck by the generational contrast between his parents' genteel lifestyle and the adventurous life of his interlocutor:

He had a narrative gift that thrilled me as scarcely any book had ever done, and when I'd go back to the croquet lawn to help mother back to our boarding-house, and be offered a cup of tea when only an hour or so before I'd been drinking the old man's home-brew, I'd feel quite sick at the thought of how tame most people's lives were. ${ }^{38}$

Like the old codger he is, Holmes is critical of the younger generation, but his critique is framed as an opposition between past 'adventure' and present 'tameness'. Whereas he had once 'struck out for himself and refused to live the tame easy life that he could have', he now feels that same 'spirit of adventure' has died out in New Zealand. ${ }^{39}$ The disappointingly

Journal of New Zealand Studies NS13 (2012), 34-45. 
settled and constrained nature of contemporary society is thus defined in opposition to his romanticized view of mobile, transnational, masculine, colonial labour.

What is doubly significant about Fred Holmes' critique of the 'tameness' of the present is the narrator's ready comprehension of it in narrative terms. Holmes' stories of a fading colonial world remind him of the novels that he avidly consumes:

Well, he told me endless tales of his adventures and I suppose they were commonplace enough. I'd read any number of stories of such adventures and had many a wild longing to experience them myself; but they seemed so far removed from the everyday life of a small country town that I supposed I'd never have the courage to make the break. But it was somewhat different hearing them firsthand from Fred Holmes. He had a narrative gift that thrilled me as scarcely any book had ever done[.] ${ }^{40}$

He would have in mind nineteenth-century romances of imperial adventure, and I shall suggest that the formal qualities and thematic concerns of such works are as suited as their content to a character such as Holmes. Although a full discussion of the adventure romance genre is beyond the scope of this essay, its general contours - and their relevance to Sargeson's alienated and wandering men - can be readily and briefly sketched. Even before the 'romance revival' in the $1880 \mathrm{~s}$, depictions of colonial space had been designated as romances, and what unites these representations at a formal level is their difference from metropolitan, bourgeois, settled space. Mikhail Bakhtin's account of the adventure novel chronotope attributes that difference to a distinctive temporality: 'Moments of adventuristic time occur at those points when the normal course of events, the normal, intended or purposeful sequence of life's events is interrupted', just as Fred Holmes' tales actively disrupt the narrator's experience of the 'quiet place up in the north there' and his acquiescence to the career path mapped out for him. ${ }^{41}$ The difference between 'adventuristic time' and the 'normal course of events' is further clarified by Ian Duncan, whose account of romance in the early-nineteenth-century stresses its fundamental anachronism. For Duncan, the romance is 'the narrative form of a historical otherness, a representation discontinuous with modern cultural formations'. ${ }^{42}$ Coupled with this distinctively pre-modern temporal orientation, the adventure romance is typically also characterized by a fragmentary or episodic structure. Bakhtin argues that such novels are 'composed of a series of short segments that correspond to separate adventures'. ${ }^{43}$ Along similar lines, Northrop Frye suggests that the romance has a 'sensational' structure, defined by the discontinuous movement from one discrete episode to another, which neatly encapsulates the formal structure of Holmes' own 'endless' yet distinctly 'episod[ic]' tales. ${ }^{44}$ To the narrator, Holmes is like a romance author, but with the added advantage that his stories are apparently real and offer an alternative to the orthodoxies of 'everyday life'.

Before exploring the significance of these formal qualities, it must first be acknowledged that, in light of the orthodoxies of Sargeson criticism, the romance is the last thing that might be expected to make an appearance in his short fiction. Discussions of Sargeson's technique have consistently drawn on his short but positive 1935 review of Sherwood Anderson to assert the modernist lineage of his realist aesthetic. ${ }^{45}$ While recent accounts have challenged the view that the writers of the 1930s and 40s were the first generation of nationalist writers, critics have continued to agree that their work constituted a radical aesthetic break from previous New Zealand writing. ${ }^{46}$ Murray's claim that the writers of the 1930 s 'radically rewrote the terms of existing literature' and 'assert[ed] the necessity of new forms' essentially reiterates E. H. McCormick's 1959 observation that 'in a few agitated years a handful of men and women produced a body of work which, in an intimate and organic sense, belonged to the country as none of its previous writings had done'. ${ }^{47}$ Moreover, the stories themselves 
occasionally hold forth against a feminized romance as a form of national false consciousness: 'You see, she reads only Ethel M. Dell and romances about Wagner and things like that. And she believes them! I mean she's preposterous enough to connect them with life right here in New Zealand in the year $1936{ }^{\prime 48}$ Yet while it would be absurd to deny the influence on Sargeson of American modernism, or to argue that he was not trying to depict contemporary New Zealand in a distinctively 'realistic' fashion, his own critical writings have long suggested that this is far from the whole story that might be told.

Among the thirty essays collected in Conversation in a Train and Other Critical Writings (1983), three stand out for their focus on Australian colonial writing. In 'Australian Fiction' (1967), ostensibly a review of collected writings from the Australian Communist publication Overland, Sargeson offers an extensive and instructive account of his interests as a youthful reader prior to his programmatic attempts at self-improvement:

I thought It's Never too Late to Mend (Charles Reade), Geoffry Hamlyn (Henry Kingsley), and Robbery Under Arms the very best books I had ever read. [...] And it all led eventually to Henry Lawson (his prose), about whose greatness I was never in doubt: it is true that I mistakenly supposed he was 'representing' an Australia which still existed, but I was right in my intuitive understanding that I was getting a literary line on what it meant to be alive and in the world anywhere at anytime. ${ }^{49}$

The first three texts named here, classic Victorian-era romances of Australia, are the seeming antithesis of Sargeson's assertion of a modernist realist aesthetic yet he strikingly refuses to disavow them in favour of the more serious works he discovered in later years. ${ }^{50}$ The surprising longevity of that enthusiasm is reflected in That his extensive 1950 review of a new edition of Robbery Under Arms (1881), Rolf Boldrewood's archetypal Australian imperial romance. Rejecting the assertion that the novel 'sound[s] like an out of date Australian "western", he finds reasons to take it seriously that have a clear bearing on his own fictional project. First there is the vernacular language of its narrator, Dick Marston, 'wonderfully fresh, alive and transfigured on the printed page, wonderfully immediate and animated', which also succeeds in attaining a broader national significance: 'Dick Marston, who speaks for himself, and at the same time unconsciously speaks for a whole continent, is a man well worth listening to'. ${ }^{51} \mathrm{He}$ goes on to read the novel as an account of men 'at war with the society of their day' who retreat into 'an entirely male world'. ${ }^{52}$ That is, rather than simply dismiss Boldrewood as derivative or escapist, Sargeson offers a (partial) defence of the ability of the colonial romance to represent a settler society in a 'realistic' and critical fashion.

In concluding, I wish to broaden the horizon of the argument to encompass another archetypal 1930s text of disenchanted, mobile masculinity, John Mulgan's Man Alone (1939). After his epic cross-country trek through the Kaimanawas, and at the very limits of his endurance, the peripatetic Johnson is relieved to stumble upon a small hut. Like Fred Holmes' shack, this one exists on the periphery of society; the track that leads to the nearest settlement was made by '[s]urveyors [...] fifty years ago', though 'God knows what for'. ${ }^{53}$ Also like Fred Holmes' shack, this hut contains an old man who once ranged across imperial space earning a living as a prize fighter and prospecting for gold: 'You'd go a long way before you found a dirtier looking bit of country than up back of the Karamea. I been in New Guinea, Australia, too. There's no good gold left now, son'. ${ }^{44}$ Bill Crawley, in other words, is another figure from the past. As a man who 'kept no calendar', he exists outside of national time as a vestigial remnant of an earlier formation of settler society. ${ }^{55}$ Johnson would seem to be his spiritual heir, yet in contrast to Crawley's withdrawal from society, he continues his centrifugal motion out beyond the borders of the nation. Their resemblance to Sargeson's 
lone and alienated men demonstrates the pervasiveness of romance elements within the critical realism of the 1930s and 40s, but it also raises the question of how this might best be accounted for.

In reconsidering the formal contours of the period, it is helpful to recall Fredric Jameson's argument in The Political Unconscious (1981) that there is no such thing as a pure genre. '[I]t would seem to follow,' he claims, 'that, properly used, genre theory must always in one way or another project a model of the coexistence or tension between several generic modes or strands'. ${ }^{56}$ While the precise identity and function of those generic modes is determined by the historical situation in which the text was produced, the presence of a romance mode is of particular interest:

As for romance, it would seem that its ultimate condition of figuration [...] is to be found in a transitional moment in which two distinct modes of production, or moments of socioeconomic theory, coexist. [...] Our principal experience of such transitional moments is evidently that of an organic social order in the process of penetration and subversion, reorganization and rationalization, by nascent capitalism, yet still, for another long moment, coexisting with the latter. ${ }^{57}$

These insights crystallize a claim that has thus far been only implicit in this essay, namely that Sargeson's figures from the past and their confreres in contemporaneous works are an epiphenomenon of one such 'transitional moment'. The specificity of this particular moment can be glimpsed by way of Allen Curnow's comments on the "capacious term "Australasia", in his introduction to the Penguin Book of New Zealand Verse (1960), which he posits as a prior cultural formation that 'meant a great deal to the New Zealand poet or journalist of the nineteenth or early twentieth century' but that is now 'separated from us by the historical crevasse into which the colonial "simplicities of life" vanished". ${ }^{58}$ If the writers of the 1930s and 40s stood on the lip of this 'historical crevasse' between colony and nation, then their employment of a romance mode effectively casts an eye back across that divide and thereby disrupts any sense that a simplistic nationalist teleology might be in play. The reworking of the adventure romance at this time, I suggest, coincides with the submergence of transTasman circulation of labour and literary forms beneath an increasingly bounded national economy and culture.

Sargeson's writings on Australian fiction demonstrate the extent of his engagement with that receding moment of trans-Tasman exchange. The review of Robbery Under Arms begins, 'Until about forty years ago Boldrewood's novel was so well known that almost anyone in Australia or New Zealand could have told you who Starlight was, or Warrigal, or Rainbow. Not today, though, at least not in New Zealand. With rare exceptions only the eyes of the oldtimers light up'. ${ }^{59}$ The forgetting of this novel, in other words, testifies to the gradual restriction of literary and cultural movement to within the national border. Lydia Wevers has similarly highlighted the inclusion of Australian modernist Max Harris in Sargeson's short fiction anthology, Speaking for Ourselves (1945), a gesture that she argues 'reglosses "ourselves" away from nationalism and towards a cultural field - modernism'. ${ }^{60}$ This gesture of transcending national boundaries in the name of literary form, I suggest, draws on and continues that earlier history of trans-Tasman cultural and political exchange. Seen in this light, the conclusion to his review of Henry Lawson's short stories, quoted in part at the beginning of this essay, takes on a new significance:

It is time to forget about his being a 'national' writer, certainly time to cease thinking of him as a 'realist'. Think instead of affinities with another 'colonial' writer - Theocritus. Like the Sicilian Greek, Lawson was completely at home with pastoral characters who 
lived not very far above the survival line. It is a curiously dour sardonic pastoral celebration of life that he engages himself with. Put cabbage-tree hats on Theocritus's goat-herds and call them shearers or rouseabouts; wipe the smiles off their faces and replace them with grins — and you are in Lawson's world. ${ }^{61}$

Sargeson's pioneering of a national realist tradition is often compared to Lawson's role in Australian literature. ${ }^{62}$ What is therefore so intriguing about this disavowal of two of the key terms most consistently associated with Sargeson's own writing — 'national' and 'realist' is that the term he instead prefers, 'colonial', is proposed not only for reasons of periodization but also because it appears more suited to describing the lone and migratory figures such as 'shearers or rouseabouts' that his own works are so interested in.

Thinking of Sargeson's short stories, and even Man Alone, as 'colonial' texts, in the way that Sargeson situated Lawson's work, allows their figures from the past to silently testify to the dismemberment of that colonial sphere under the pressures of nationalism. Rollo Arnold has highlighted 'steady two-way trans-Tasman population movements' from 1880, which he dubs the 'Perennial Interchange'. ${ }^{63}$ The most significant of these movements were constituted by seasonal agricultural labourers, a loosely organized and constantly reforming pool of labourers whose mobility is described by Belich as 'more a semi-nomadic, cyclical, progresspatterned type of movement than full nomadism' ${ }^{64}$ This 'crew culture', as he terms it, was fundamentally transnational in nature:

It dwelt less in countries than between them [...] There is a sense in which they were in New Zealand, but not of it, though New Zealand history owns them as much as anywhere else [...] Their culture was neo-British and Irish, their argot a 'Lingua Britannica'. Like other folk cultures, theirs did not care about patents, plagiarisms and retrospective nationalisms. Its local vestige was an Australasian layer of culture, claimed by each side of the Tasman without full acknowledgement of the other. ${ }^{65}$

Seen from the internationalist perspective of the left in the 1930s, the colonial period could be associated with a positive, even utopian, valence. ${ }^{66}$ Certainly, as James Bennett points out, during the early decades of the century, 'Of the variety of levels at which an Australian-New Zealand relationship can be said to have operated, there is considerable evidence to suggest that trans-Tasman labour bonds, notably between the militant wings, were among the most vital forces for a cohesive Australasian community'. ${ }^{67}$ The anachronistic persistence of figures of the past such as Fred Holmes and Bill Crawley therefore attests to possibilities that were simultaneously pre-national and trans-national. If those trans-Tasman genealogies were inevitably rendered invisible in the post-1930s climate of cultural nationalism, then it is no coincidence that they have returned to visibility at a moment when New Zealand culture is once again acknowledging its transnational dimensions.

\footnotetext{
${ }^{1}$ I am indebted to the comments offered by Dougal McNeill on an earlier draft of this essay. I would like to dedicate this essay to Linda Hardy, as a small token of gratitude for the lasting influence of her teaching and scholarship.

${ }^{2}$ Frank Sargeson, 'The Making of a New Zealander', in Janet Wilson, ed., Frank Sargeson's Stories, Auckland, 2010, p.104.

${ }^{3}$ Ibid., p.105.

${ }_{5}^{4}$ Ibid., p.108.

${ }^{5}$ Ibid., p.109.

${ }^{6}$ Frank Sargeson, 'An Affair of the Heart', in Janet Wilson, ed., Frank Sargeson's Stories, Auckland, 2010, p.57.

Ibid., pp.60, 57.

${ }^{8}$ Ibid., p.55.
} 
${ }^{9}$ Ibid., p.59.

${ }^{10}$ Stephen Turner, 'Settlement as Forgetting', in Hilary Ericksen, Klaus Neumann, and Nicholas Thomas, eds., Quicksands: Foundational Histories in Australia and Aotearoa New Zealand, Sydney, 1999, p.28.

${ }^{11}$ John Newton, "'Shepherds Who Call Each Other Darling": Writing around Homophobia in Sargeson and Glover', New Literatures Review, 38 (2002), p.37.

${ }^{12}$ Ibid.,, pp.37, 38, 40.

${ }^{13}$ Patrick Evans, The Long Forgetting: Post-Colonial Literary Culture in New Zealand, Christchurch, 2007, pp.128, 132.

${ }^{14}$ Dan Davin, 'The Narrative Technique of Frank Sargeson', in Helen Shaw, ed., The Puritan and the Waif: A Symposium of Critical Essays on the Work of Frank Sargeson, Auckland, 1955, p.57.

${ }^{15}$ In a similar fashion, Patrick Evans observes a paradox in 'the cultural nationalists' tendency to think of themselves in gardening terms - as ... learning to "live with the land" in order to find "the familiar earth of plain speech": "The significance of this imagery is its connection to its opposite: everything involving intervention on the land and everything involving the controlling and manipulation of nature'. Evans, pp.131-32.

${ }^{16}$ Frank Sargeson, 'Just Trespassing, Thanks', in Janet Wilson, ed., Frank Sargeson's Stories, Auckland, 2010, p.247.

${ }^{17}$ Frank Sargeson, ‘Old Man's Story', in Janet Wilson, ed., Frank Sargeson's Stories, Auckland, 2010, p.120.

${ }^{18}$ Ibid., p. 120 .

${ }^{19}$ Ibid., pp.120, 121.

${ }^{20}$ Frank Sargeson, Sargeson, Auckland, 1981, p.55.

${ }^{21}$ Michael King, Frank Sargeson: A Life, Auckland, 1995, p.103.

${ }^{22}$ Ibid., p.104.

${ }^{23}$ Miles Fairburn, The Ideal Society and Its Enemies: The Foundations of Modern New Zealand Society, 18501900, Auckland, 1989.

${ }^{24}$ Fairburn, p.192.

${ }^{25}$ Ibid., p.266.

${ }^{26}$ James Belich, Making Peoples: A History of the New Zealanders: From Polynesian Settlement to the End of the Nineteenth Century, Auckland, 1996, p.422.

${ }^{27}$ Lawrence Jones, Barbed Wire \& Mirrors: Essays on New Zealand Prose, $2^{\text {nd }}$ ed., Dunedin, 1990, pp.297, 301.

${ }^{28}$ Erik Schwimmer, 'A Picaresque View of Life', in Helen Shaw, ed., The Puritan and the Waif: A Symposium of Critical Essays on the Work of Frank Sargeson, Auckland, 1955, pp.47-48.

${ }^{29}$ Monte Holcroft, Discovered Isles, Christchurch, 1950, pp.20-21.

${ }^{30}$ Ibid., p.32.

${ }^{31}$ Stuart Murray, Never a Soul at Home: New Zealand Literary Nationalism and the 1930s, Wellington, 1998, p.138.

${ }^{32}$ Ibid., p. 140 .

${ }^{33}$ Newton, pp.35, 37. Murray claims that 'Sargeson's early stories intersect with the orthodoxies of English writing', p.152.

${ }^{34}$ Frank Sargeson, 'Last Adventure', in Janet Wilson, ed., Frank Sargeson's Stories, Auckland, 2010, p. 83.

${ }^{35}$ Ibid., p.85.

${ }^{36}$ Belich, p.436.

${ }^{37}$ Sargeson, 'Last Adventure', p. 84 .

${ }^{38}$ Ibid., p.85.

${ }^{39}$ Ibid., p.86.

${ }^{40}$ Sargeson, 'Last Adventure', pp.84-85.

${ }^{41}$ M.M. Bakhtin, 'Forms of Time and of the Chronotope in the Novel', in Michael Holquist, ed., The Dialogic Imagination: Four Essays, translated by Caryl Emerson and Michael Holquist, Austin, 1981, p.95; Sargeson, 'Last Adventure', p.83.

${ }^{42}$ Ian Duncan, Modern Romance and Transformations of the Novel: The Gothic, Scott, Dickens, Cambridge, 1992, pp.57-58.

${ }^{43}$ Bakhtin, , p.91.

${ }^{44}$ Northrop Frye, The Secular Scripture: A Study of the Structure of Romance, Cambridge; London, 1976, p.47. Northrop Frye, The Secular Scripture and Other Writings on Critical Theory, 1976-1991, Joseph Adamson and Jean Wilson, eds., Toronto, 2006), pp.3-124.

${ }^{45}$ See Frank Sargeson, 'Sherwood Anderson', in Kevin Cunningham, ed., Conversation in a Train: And Other Critical Writing, Auckland, 1983, pp.15-17. Melissa Gniadek comments, 'The first phase of Sargeson's career seemed to ask similar questions [to Anderson] through his stories peopled with working-class, inarticulate characters whose speech was conveyed in a vernacular that was new to New Zealand literature, stories that are often credited with giving New Zealanders a distinctive literary voice and with capturing the spirit of a nation'. 
Melissa Gniadek, 'The Art of Becoming: Sherwood Anderson, Frank Sargeson and the Grotesque Aesthetic', Journal of New Zealand Literature, 23, 2 (2005), p.22. See also Lawrence Jones' discussion of the cultural nationalists' appropriation of American literary models, Picking up the Traces: The Making of a New Zealand Literary Culture, 1932-1945, Wellington, 2003, pp.160-67.

${ }^{46}$ Jane Stafford and Mark Williams have argued that 'Maoriland constituted the first generation of cultural nationalism in New Zealand, less radical and more tentative than the second', while Stuart Murray has sought to assert a perspective on the writing of the 1930s as 'one country, among others, wrestling with the legacy of a British colonial heritage'. Murray, p.18; Jane Stafford and Mark Williams, Maoriland: New Zealand Literature, 1872-1914, Wellington, 2006, p.14.

${ }^{47}$ Murray, p.10. McCormick is quoted in Jones, Picking up the Traces, p. 15.

${ }^{48}$ Frank Sargeson, 'In the Midst of Life', in Janet Wilson, ed., Frank Sargeson's Stories, Auckland, 2010, p.31.

${ }^{49}$ Frank Sargeson, 'Australian Fiction', in Kevin Cunningham, ed., Conversation in a Train: And Other Critical Writing, Auckland, , 1983, p.135.

${ }^{50}$ For Reade and Kingsley, see Coral Lansbury, Arcady in Australia: The Evocation of Australia in NineteenthCentury English Literature, Carlton, 1970, pp.108-22; for Boldrewood, see Robert Dixon, Writing the Colonial Adventure: Race, Gender and Nation in Anglo-Australian Popular Fiction, 1875-1914, Cambridge, 1995, pp.32-8.

${ }^{51}$ Frank Sargeson, 'Rolf Boldrewood: Robbery under Arms', in Kevin Cunningham, ed., Conversation in a Train: And Other Critical Writing, Auckland, 1983), pp.43, 44. Michael King recounts that Sargeson first began 'to read systematically and to deliberately extend his written and spoken vocabulary' in Auckland in the mid1920s, and attempted a much more ambitious project in the British Museum in 1927. King, pp.58, 78.

52 Sargeson, 'Rolf Boldrewood', pp.44, 45.

${ }^{53}$ John Mulgan, Man Alone, Auckland, 2002, p.160.

${ }^{54}$ Ibid., p. 153.

55 Ibid., p. 155.

${ }^{56}$ Fredric Jameson, The Political Unconscious: Narrative as a Socially Symbolic Act, Ithaca, 1981, p.141.

${ }^{57}$ Ibid., p. 148.

58 Allen Curnow, 'Introduction', in Allen Curnow, ed., The Penguin Book of New Zealand Verse, Harmondsworth, 1960, pp.27, 29.

${ }^{59}$ Sargeson, 'Rolf Boldrewood', p.42.

${ }^{60}$ Lydia Wevers, 'Speaking for Ourselves in 1945', Journal of New Zealand Literature, 16 (1998), pp.97-111.

${ }^{61}$ Frank Sargeson, 'Henry Lawson: Some Notes after Re-Reading', in Kevin Cunningham, ed., Conversation in a Train: And Other Critical Writing, Auckland, 1983, p.125.

${ }^{62}$ Stafford and Williams discuss the trans-Tasman dimension of Lawson's career in Stafford and Williams in Maoriland, pp.85-109. For a comparison of Lawson and Sargeson, see Lydia Wevers, 'An Invention of the Real: The Nationalisms of Henry Lawson and Frank Sargeson', Australian and New Zealand Studies in Canada, 12 (1994), pp.123-34.

${ }^{63}$ Rollo Arnold, 'The Australasian Peoples and Their World, 1888-1915', in Keith Sinclair, ed., Tasman Relations: New Zealand and Australia, 1788-1915,Auckland, 1987, p.53.

${ }^{64}$ Belich, p.436.

${ }^{65}$ Belich, p.436.

${ }^{66}$ The majority of Sargeson's early stories were published in Tomorrow, the 'principal forum in New Zealand for the discussion of issues and international developments of left-wing culture in the 1930s'. The critique of New Zealand society and culture levelled by its most prominent columnists, who were often of Australian extraction or had spent time there, was 'undoubtedly sharpened by the contrast it made with Australia'. Rachel Barrowman, A Popular Vision: The Arts and the Left in New Zealand, 1930-1950, Wellington, 1991, pp.27, 47.

${ }^{67}$ James Bennett, 'The Contamination of Arcadia? Class, Trans-National Interactions and the Construction of Identity, 1890-1913', New Zealand Journal of History, 33, 1 (1999), p.20. 